\title{
The Effect of University Missions on Entrepreneurial Initiative across Multiple Entrepreneurial Ecosystems: Evidence from Europe
}

\author{
Mariana Pita ${ }^{1,2, *(\mathbb{D})}$, Joana Costa ${ }^{1,2,3}$ (D) and António Carrizo Moreira $1,2,3$ (D) \\ 1 DEGEIT-Department of Economics, Management, Industrial Engineering and Tourism, \\ University of Aveiro, Campus Universitário de Santiago, 3810-193 Aveiro, Portugal; joanacosta@ua.pt (J.C.); \\ amoreira@ua.pt (A.C.M.) \\ 2 GOVCOPP-Research Unit on Governance, Competitiveness and Public Policies, University of Aveiro, \\ Campus Universitário de Santiago, 3810-193 Aveiro, Portugal \\ 3 INESCTEC - Institute for Systems and Computer Engineering, Technology and Science, Campus da \\ Faculdade de Engenharia da Universidade do Porto, Rua Dr. Roberto Frias, 4200-465 Porto, Portugal \\ * Correspondence: mariana.pita@ua.pt
}

check for

updates

Citation: Pita, M.; Costa, J.; Moreira, A.C. The Effect of University Missions on Entrepreneurial Initiative across Multiple Entrepreneurial Ecosystems: Evidence from Europe. Educ. Sci. 2021, 11, 762. https://doi.org/ 10.3390/educsci11120762

Academic Editors: Jacinto Jardim and Howard Woodhouse

Received: 20 September 2021

Accepted: 17 November 2021

Published: 25 November 2021

Publisher's Note: MDPI stays neutral with regard to jurisdictional claims in published maps and institutional affiliations.

Copyright: (C) 2021 by the authors Licensee MDPI, Basel, Switzerland. This article is an open access article distributed under the terms and conditions of the Creative Commons Attribution (CC BY) license (https:// creativecommons.org/licenses/by/ $4.0 /)$.

\begin{abstract}
Entrepreneurial universities are a significant element of entrepreneurial ecosystems and aspire to foster entrepreneurial initiative through their "third mission". However, while entrepreneurial ecosystems are scrutinized using a contextual approach to detect differences and similarities and how they affect entrepreneurship, little is known about how entrepreneurial universities impact entrepreneurial initiatives in general, considering multiple environments. Drawing on entrepreneurial university and entrepreneurial ecosystem theories, a conceptual framework is proposed that aims to explain the effect of the entrepreneurial university on an entrepreneurial initiative through its three "missions", using an entrepreneurial ecosystem taxonomy. Based on individual data from the Global Entrepreneurship Monitor, this entrepreneurial initiative analyzed 18 European countries in 2017. The results do not generally support the importance of entrepreneurial universities to entrepreneurial initiative. The relevance of entrepreneurial universities increases in more fragile entrepreneurial ecosystems since individuals need support over multiple dimensions. Conversely, the entrepreneurial universities that are embedded in stronger entrepreneurial ecosystems lose relevance and negatively affect the entrepreneurial initiative. Therefore, the value of entrepreneurial universities is reduced when individuals receive greater support from other dimensions. The variations across both groups suggest that the concept of entrepreneurial universities is not a contemporaneous phenomenon; however, their effect is progressively revealed by the maturity of each university's mission. This perspective substantially changes the understanding of entrepreneurial universities as a thwartwise strategy, suggesting that the universities' impact is expanded as their missions gradually evolve. Overall, the study contributes to an understanding of the implications for universities that blindly follow entrepreneurship, neglecting the exogenous environment, namely, the entrepreneurial ecosystem and individual drive.
\end{abstract}

Keywords: entrepreneurial ecosystem; entrepreneurial initiative; entrepreneurial university; Global Entrepreneurship Monitor

\section{Introduction}

The discussion around entrepreneurial ecosystems (EEs) and entrepreneurial initiative (EI) in Europe, and how Europe can prosper in a global, complex and competitive environment through entrepreneurship, has gained relevance at both the academic [1-3] and European policy levels [4,5]. For decades, the United States served as an example of entrepreneurship, evidencing successful strategies for promoting new businesses and vibrant entrepreneurial ecosystems when compared to Europe or other old-world regions [6]. 
Hotbeds of entrepreneurship such as "Silicon Valley" gained prominent attention from academics, scholars, and practitioners [7], moved by the aspiration of discovering a "successful recipe" capable of replication on European ground. After several economic and social crises, Europe was lagging behind other regions [8]. Therefore, placing entrepreneurship as a driver to foster economic growth via new sources of employment, the levels of innovation and competitiveness were evident. The reignition of the entrepreneurial spirit in Europe become a common goal, as stated in the Entrepreneurship 2020 Action Plan, indicating the creation of ecosystems where entrepreneurs can flourish and grow as a priority [5].

In this renewed European strategy, universities were considered a key instrument in improving EI through the expansion of its three missions, going beyond education and research and bridging the gap between new knowledge and industry [9]. This prominent role of universities entailed producing, transferring, and applying knowledge to society, evidencing the connection with the triple helix model [10]. The involvement of universities in forming new ventures represented a revolution at the institutional level regarding university-industry-government interaction, originating the so-called "third mission" [10]. This transformative process resulted from the need to broaden the usual economic conditions to generate innovation. Universities actively contribute to the development of entrepreneurial ecosystems. They provide a skillful labor force and catalyze new businesses, like start-ups or spin-offs [11], and support industry advancements through joint projects and research development. As the role of universities gains centrality within entrepreneurial ecosystems, the relevance of the "third mission" to education and research raises doubts about how universities should contribute to entrepreneurship [12].

In parallel, the recent literature legitimizes the importance of EEs to promote employment, economic growth, and development [13] through the creation of new ventures. EEs result from the combination of institutional, human, financial and cultural factors [14] within geographical boundaries [15], confirming the existence of unique, sheltered systems with place-based conditions. The formation of entrepreneurial ecosystems has gained importance, as demonstrated by the extensive literature [16-19], with studies focusing on structure [20], evolution [21], process [3] or geography [22]. However, the concept's attractiveness has led to a misconception around its complexity and an obscured understanding of its interdependent elements [14] when applied to different ecosystems. While these studies provide some focus, more adequate research is needed to clearly define the effect of entrepreneurial ecosystems on entrepreneurship, with demarcated analysis at national, regional, or local levels connecting the distinctive actors [1].

A narrow analysis of EEs and their elements can result in problematic shortcomings. First, there is a generalized expectation around the benefits of EEs, neglecting the idiosyncrasies of their placement. The desire to overcome fragilities at economic and social levels creates pressure to implement entrepreneurship measures quickly, without recognizing the goal of such an intervention. For example, national strategies that follow unbalanced dissemination can increase the disparities between individuals who aim to start a business. Second, the development of EEs entails assessing their quality and analyzing their effectiveness. The encouragement of EEs depends on orchestrating several actors in balanced participation to avoid misguidance. Third, institutional efforts envisage education, research, and knowledge transfer activities being sufficient to stimulate entrepreneurial initiative.

Nevertheless, universities must identify the impact of their missions on entrepreneurship and determine effective strategies according to the internal and external context. Finally, there is considerable variation regarding individuals' determinants and the context, resulting in a multidimensional influence. Ignition of the entrepreneurial initiative is conditioned concurrently by several dimensions, compelling differentiated strategies toward entrepreneurship.

With the substantial investment in entrepreneurship among European countries, the lack of evidence around the impact of the entrepreneurial universities (EUs) on EI is unexpected. Alongside, there is limited empirical research about the influence of EEs on EI. Therefore, the contribution of the EUs regarding EI is underrepresented in the existing 
literature, which notably focuses on different EEs, characterizing the gap for the present study. Against this background and drawing insights from Bosma [23] and Stam and van de Ven [14], the primary purpose of this work is to examine the role of entrepreneurial universities in entrepreneurial initiative through the lens of entrepreneurial ecosystem quality, focusing on the European arena.

The proposed model encompasses two main assumptions. First, the model was elaborated by relying on prior research, placing the EUs as a central tenet to promote entrepreneurial initiative, containing its three missions: education, research, and entrepreneurship. Second, entrepreneurial ecosystems exhibit multiple profiles, which can have a different impact on the entrepreneurial initiative. The different profiles are captured by the entrepreneurial ecosystem quality (as a result of an equivalent contribution from each dimension) and entrepreneurial initiative. Although other studies sought to measure entrepreneurial ecosystems [19], the purpose of this four-quadrant taxonomic approach is to categorize EEs: Die-Hard (low EEQ; low EI), Go-Getter (low EEQ; high EI), Sugar-Coated (high EEQ; low EI) and Front-Runners (high EEQ; high EI).

Therefore, the study aims to address the following research questions: Does the entrepreneurial university promote entrepreneurial initiative? Is the effect of the entrepreneurial university on entrepreneurial initiative context-dependent?

The data are derived from the Global Entrepreneurship Monitor (GEM) [24,25] and European Innovation Scoreboard (EIS), following individual and country-level indicators.

This study constitutes interesting empirical research for two main reasons. First, the European context offers fertile ground to explore the effect of the EUs on EI, as Europe adopted a strong commitment toward entrepreneurship that included the transformation of institutions, the leverage of human capital and the reinforcement of support conditions. Second, EEs profiles reflect geographical boundaries; therefore, although European countries follow a common entrepreneurship strategy, the study will allow an appraisal of whether the EUs has different effects, depending on the context.

The chapter presents the following structure. First, Section 2 offers an overview and cross-section of the concept's entrepreneurial ecosystems, entrepreneurial universities, and entrepreneurial initiative. Then, Section 3 describes the methodology, while Section 4 summarizes the research methods. Section 5 is devoted to results and discussion. Finally, Section 6 offers our conclusion and outlines the limitations and implications of the study, with future research avenues.

\section{Conceptual Framework and Hypotheses}

\subsection{Entrepreneurial University}

The university landscape has undergone a dramatic revolution in the last couple of decades due to numerous transformations. These changes have taken place in the context of a perceived crisis where universities started to question their own quality, efficiency and relevance [26], along with declining financial support and competitive pressure among peers [27]. Within this setting, the survivability of universities was brought into question due to access to limited resources or the adoption of traditional non-commercial models. This dramatic change pushed a significant transformation of universities toward more flexible, creative, diversified, solid and integrated models [28]. Therefore, becoming entrepreneurial was the answer for universities to a contemporary problem [29], even if their culture or assets were not favorable [27]. Indeed, universities adopted a more robust commitment to economic needs, reinforcing the so-called "third mission", sometimes disregarding Mode 1 and Mode 2. However, the effectiveness of universities in this new role was regarded as unbalanced, as their capabilities to thrive or general conditions were not fully established [27].

The literature on EUs is commonly articulated via the triple helix model, evidencing the importance of cross-pollination to reach innovative solutions and entrepreneurial projects (see Table 1). 
Table 1. Definitions of entrepreneurial universities and their activities.

\begin{tabular}{|c|c|c|}
\hline Author(s), Years & Definition & Activities \\
\hline $\begin{array}{c}\text { Guerrero, Cunningham, and } \\
\text { Urbano [30] }\end{array}$ & $\begin{array}{c}\text { "The entrepreneurial university serves as a conduit of } \\
\text { spillovers contributing to economic and social development } \\
\text { through its multiple missions of teaching, research, and } \\
\text { entrepreneurial activities." }\end{array}$ & $\begin{array}{l}\text { Teaching, research, } \\
\text { entrepreneurship. }\end{array}$ \\
\hline Urbano and Guerrero [31] & $\begin{array}{l}\text { "Entrepreneurial universities have emerged as central actors } \\
\text { playing an active role in promoting teaching, innovation, } \\
\text { knowledge transfer, and entrepreneurship." }\end{array}$ & $\begin{array}{l}\text { Teaching, research, } \\
\text { knowledge transfer, } \\
\text { entrepreneurship. }\end{array}$ \\
\hline Audretsch and Keilbach [13] & $\begin{array}{c}\text { "An entrepreneurial university can be any university that } \\
\text { contributes and provides leadership for creating } \\
\text { entrepreneurial thinking, actions, institutions and } \\
\text { entrepreneurship capital." }\end{array}$ & $\begin{array}{l}\text { Entrepreneurial thinking } \\
\text { and action. }\end{array}$ \\
\hline Hannon [32] & $\begin{array}{c}\text { "An entrepreneurial university can be defined as a university } \\
\text { that finds new solutions to address the pressures and } \\
\text { challenges that stem from an uncertain and unpredictable } \\
\text { environment." }\end{array}$ & Entrepreneurial orientation. \\
\hline Siegel and Wright [27] & $\begin{array}{l}\text { "Universities are increasingly being viewed as } \\
\text { 'entrepreneurial', who can use the knowledge created } \\
\text { internally to pursue commercial objectives based on sound } \\
\text { financial considerations." }\end{array}$ & Knowledge transfer. \\
\hline $\begin{array}{c}\text { Philpott, Dooley, Oreilly, and } \\
\text { Lupton [33] }\end{array}$ & $\begin{array}{l}\text { "A university that embraces its role within the triple helix } \\
\text { model and adopts the mission of contributing to } \\
\text { regional/national development is referred to as an } \\
\text { 'entrepreneurial university'." }\end{array}$ & $\begin{array}{l}\text { Teaching, research, } \\
\text { entrepreneurship. }\end{array}$ \\
\hline Carayannis et al. [6] & $\begin{array}{l}\text { "Universities of new functions-scientific and technical } \\
\text { entrepreneurship, business incubation, the creation of new } \\
\text { companies, and the implementation of innovative projects." }\end{array}$ & $\begin{array}{l}\text { Teaching, research, } \\
\text { entrepreneurship. }\end{array}$ \\
\hline D'Este and Perkmann [34] & $\begin{array}{l}\text { "Implicit in the many accounts of the entrepreneurial } \\
\text { university is the assumption that academic researchers engage } \\
\text { with industry in order to commercialize their knowledge." }\end{array}$ & Knowledge transfer. \\
\hline
\end{tabular}

Source: Authors' own elaboration.

The collaboration between industry and universities emerges as a driver of technological development and competitiveness [35]. Still, this only occurs when both actors broaden their activities. The exploitation and transformation of knowledge into economic value have become a priority for Europe, instigating linkages between private and public sectors, with academia taking a central role. This new model emphasizes the entrepreneurial culture of universities and represents the transformation of teaching and research activities toward entrepreneurial objectives. While European universities were attempting to modulate a new system, attracted by economic benefits, US universities were already exhibiting foundational pillars for successful technology commercialization with material infrastructures, innovation courses, superior entrepreneurship education, and techniques to foster entrepreneurial culture [6].

Universities accepted the third mission as a mandatory strategy that resulted in the implementation of entrepreneurship courses, research that was entrepreneurshiporiented, specific training programs to accelerate business ideas, business incubators and entrepreneurship labs to foster an entrepreneurial environment and prepare individuals to follow entrepreneurial careers [36].

Entrepreneurial universities are involved in partnerships, networks and other relationships to generate an umbrella for interacting and collaborating [37]. Their contribution provides leadership for creating entrepreneurial thinking, actions, and entrepreneurship capital [13]. 
The association between EUs and economic development is widely recognized [38]. Moreover, the contribution of universities to developing human capital and producing new knowledge is of unquestionable benefit to a knowledge-based economy. As a result, universities gained legitimacy to expand their role, beyond teaching and researching toward a "Mod' 3", becoming institutional pillars of EEs. Still, transferring their scientific and technological outputs to society at large continues to be a challenge.

The transformation of universities unlocked the "third mission" as a strategy to stimulate innovation, entrepreneurship, and sustainable development [39] through linkage with external actors. To this end, universities established relations and networks with a wide range of economic actors [40] to enable the transfer and exploitation of knowledge, acting as a natural incubator [37] for those who aim to set up a business. Furthermore, the gradual extension of their activities supported the technology transfer process and founded incubators to assist the development of firms [41].

Universities are seen as silos of knowledge that are oriented toward training highly skilled people and producing leading-edge scientific progress capable of being transformed into commercial value [3]. By accepting their involvement in this new task, universities embraced economic and social development as a mission, demonstrating their ambidextrous ability [42] to underpin innovation and economic progress. Moreover, entrepreneurship is valuable because it can convert knowledge into economic benefits that otherwise would remain uncommercialized [13]. Thus, the entrepreneurial university relies on the assumption that academic researchers interact with industry to commercialize their knowledge and engage in academic entrepreneurship [34]. Moreover, the motivations for collaboration efforts are mainly related to commercialization, learning and access to resources. Results from the study also suggest that efforts to foster entrepreneurial universities neglect researchers; academic interests and motivations can endanger the potential impact on entrepreneurship. The work developed by Sengupta and Ray [43] examined the importance of the second and third missions and discovered that research performance strengthens knowledge transfer, pushing the need to have high-quality research standards capable of attracting commercialization efforts.

Universities are houses and even colleges of entrepreneurship [44]. This represents a considerable change for European universities, with implications at several (institutional, legal, and economic) levels. At the same time, in the United States, this was already a well-known approach to technology commercialization [6]. Pressured to adopt different functions, universities acted proactively to enhance entrepreneurial behavior through education, research, and knowledge transfer without clear reasoning about the effect or specific place-based strategies. Moreover, the engagement between academy and industry has a widespread impact, envisioning a more complex picture undertaken by the entrepreneurial ecosystem concept. In this setting, EUs consist of communities organized around education, research and entrepreneurial activities, which are central to bringing entrepreneurs together and helping them to shape their networks [3]. Overall, there are reasons to argue that entrepreneurial universities stimulate a more favorable environment for students and academics to pursue entrepreneurship. Consequently, entrepreneurial education and entrepreneurial activities create a more robust entrepreneurial climate, enhancing the desire to pursue entrepreneurial careers. Moreover, as EUs are more engaged with external actors and partners, the flow of knowledge is intensified, contributing to the establishment of businesses. Following the literature, Hypothesis 1 is formulated:

Hypothesis 1. The entrepreneurial university positively affects entrepreneurial initiative.

Hypothesis 1a. The entrepreneurial university's first mission positively affects entrepreneurial initiative.

Hypothesis $\mathbf{1 b}$. The entrepreneurial university's second mission positively affects entrepreneurial initiative. 
Hypothesis 1c. The entrepreneurial university's third mission positively affects entrepreneurial initiative.

\subsection{Entrepreneurial Ecosystems}

As a response to the entrepreneurship imperative [37], EEs have moved to the forefront of entrepreneurship research in recent years. They have recalled the attention of policymakers to the need for a strategy that stimulates economic prosperity [43]. While entrepreneurs are key players in developing entrepreneurship, the surrounding ecosystem's influence on their decisions becomes evident [45].

As a result, after decades of study devoted to understanding entrepreneurship through the lens of individuals, the research evolved to appraise the phenomenon from a contextual perspective. Nevertheless, the underlying mechanisms that influence entrepreneurs remain unrevealed, showing the nascent stage of research into entrepreneurial ecosystems [22].

The concept of entrepreneurial ecosystems was observed through diverse perspectives, undermining its theoretical strength despite its attractiveness. For instance, the integrative model proposed by Stam and van de Ven [14] relies on a quantitative study to define and measure the ten elements (comprising physical infrastructure, demand, intermediaries, talent, knowledge, leadership, finance, formal institutions, culture, network) of an entrepreneurial ecosystem. The relation between EEs and EI reflects a system that is strongly dependent on territorial characteristics. The work of Cantner et al. [46] advances a dynamic lifecycle model that captures the fluctuations of entrepreneurs, considering the ecosystem lifecycle, based on the evolutionary model of entrepreneurial ecosystems developed by Mack and Mayer [21]. The model denotes the importance of entrepreneurs and their role in grasping opportunities as they evolve along with the EE's development. From a different perspective, Spigel and Harrison [3] view EEs as an ongoing process catalyzed by the local environment and specific knowledge base resources. Finally, the spatial-based framework proposed by Dubina et al. [47] raises the "helix" archetype and links innovation and entrepreneurship systems through an institutional environment demonstrating a regional/national application.

The multiple perspectives around evidenced spillover benefits on entrepreneurship are grounded on regional variations, nurturing interest in understanding how EEs components influence EI according to geographic delimitation [48]. Furthermore, acknowledging the inequality of opportunities around entrepreneurship has stressed the power of external forces [49], emphasizing the spatial concentration of entrepreneurial initiative.

In his seminal work, Isenberg defines EEs as a set of individual elements combined in complex ways [50]. The author acknowledges the importance of having a holistic system to foster and sustain entrepreneurship based on several principles, namely, that EEs: should not be induced by the desire to replicate successful models such as Silicon Valley or Boston; should be adjusted to local conditions and realities; should be a result of a fruitful relationship between private and public stakeholders; management must favor specific segments of the population that exhibit high levels of potential; should use successful cases as role models to push entrepreneurship; entangles an acculturation process with entrepreneurship being widely disseminated through culture; EEs must rely on an economic model where resources are adjusted; should be organically developed; and finally, the regulatory framework, both legal and bureaucratic, must allow a holistic perspective around entrepreneurship. Implementing systems to foster entrepreneurship at regional and national levels becomes a recurrent theme; nevertheless, the formula that influences its success is unknown. Several authors have attempted to identify the elements of EEs and find a definition to portray the phenomenon (see Table 2). 
Table 2. Definitions of Entrepreneurial Ecosystems.

\begin{tabular}{|c|c|}
\hline Author(s), Years & Definition \\
\hline Mack and Mayer [21] & $\begin{array}{c}\text { "Entrepreneurial ecosystems consist of interacting components, } \\
\text { which foster new firm formation and associated regional } \\
\text { entrepreneurial activities." }\end{array}$ \\
\hline Stam [20] & $\begin{array}{c}\text { "Entrepreneurial ecosystems are a set of interdependent actors } \\
\text { and factors coordinated in such a way that they enable } \\
\text { productive entrepreneurship." }\end{array}$ \\
\hline Mason and Brown [51] & $\begin{array}{l}\text { "A set of interconnected entrepreneurial actors, entrepreneurial } \\
\text { organizations, institutions and entrepreneurial processes which } \\
\text { formally and informally coalesce to connect, mediate and govern } \\
\text { the performance within the local entrepreneurial environment." }\end{array}$ \\
\hline $\begin{array}{c}\text { Feldman, Siegel, and } \\
\text { Wright [52] }\end{array}$ & $\begin{array}{c}\text { "Entrepreneurial ecosystems may be conceived in terms of } \\
\text { institutional, geographic, economic, or industrial contexts and can } \\
\text { be analyzed at different levels of aggregation (e.g., firms, } \\
\text { industries, universities, regions and nations)." }\end{array}$ \\
\hline Spigel and Harrison [3] & $\begin{array}{c}\text { “Ongoing processes of the development and flow of } \\
\text { entrepreneurial resources such as human and financial capital, } \\
\text { entrepreneurial know-how, market knowledge and } \\
\text { cultural attitudes." }\end{array}$ \\
\hline
\end{tabular}

Typically, the definitions rely on identifying elements and the interdependency between actors, encompassing elements, institutions, and processes [49] within a given geographic region or place [45]. Thus, EEs provide a conceptual framework where entrepreneurs, entrepreneurial climate and entrepreneurial elements are interconnected towards the necessary economic and social support to foster entrepreneurship.

Instigated by the conviction that "good entrepreneurial ecosystems can produce successful entrepreneurship", stakeholders have supported the development of EEs without having a clear understanding of how it benefits entrepreneurs to act [14,22]. Carayannis et al. [6] expose similarities in EE development, particularly in countries that are lagging behind regarding technology commercialization and entrepreneurship vibrancy. Commonly, countries that aim to promote innovation and entrepreneurship start by investing in physical infrastructures and support measures, neglecting the relevance of developing an entrepreneurial culture, solid teams and an innovative environment. According to the perspective offered by Mack and Mayer [21], the evolution of an EE brings changes to the interactions between its elements, which calls for differentiated policies to maintain systems over time.

EEs result from a combination of resources and institutions and can be scrutinized at different levels of aggregation (e.g., firms, industries, universities, regions, and nations) [53], with entrepreneurship as the ultimate output [16]. The positive mixture of EE components and relationships should allow entrepreneurs to move easily and quickly through the entrepreneurial process [54].

The literature suggests that a partial set of factors influences the predominance of entrepreneurship in certain regions [53], as evidenced by the entrepreneurial ecosystem taxonomy proposed by Pita, Costa, and Moreira [55].

From an ecosystem perspective, entrepreneurial initiative can be nurtured from the culture of an ecosystem through contact with other entrepreneurs and companies [3], forming a supply of entrepreneurial resources. The creation of new ventures demands extensive resources, commonly obtained externally due to a lack of internal opportunities. Infrastructures like universities are necessary ingredients for transformative entrepreneurship since they aggregate talent, research laboratories and incubators to promote a steady flow of linkages [56]. However, adopting a narrow, weak approach to entrepreneurship, based on entrepreneurship training but overlooking the relevance of risk acceptance and 
entrepreneurial initiative, can result in flawed strategies [56]. Although the risk of failure discourages individuals from entrepreneurship, particularly in European territories, failed entrepreneurs possess valuable knowledge, skills, and experience that contribute to creating more sustainable ecosystems [15].

Although universities act as accelerators of new businesses, using education and research to influence entrepreneurial initiative, a poor entrepreneurial culture around the academic community will not act as a magnet for promising entrepreneurs but instead only draw those who need it [57]. On the other hand, the entrepreneurial orientation of universities stimulates entrepreneurial behavior by creating a favorable environment for those who want to engage in new venture creation [58].

Therefore, entrepreneurial ecosystems seem to fuel entrepreneurial initiative with linkages between multiple stakeholders and encourage new venture creation [44].

Hypothesis 2. The effect of the entrepreneurial university on entrepreneurial initiative is affected by entrepreneurial ecosystem quality.

\subsection{Conceptual Framework}

Bercovitz et al. [56] proposed that university missions must go beyond research and education, including knowledge transfer and commercialization activities, arguing that closer partnerships between academia, industry and government are essential ingredients when interpreting such a new mission. The transformation of universities toward entrepreneurship occurs within the entrepreneurial economy [59], where new alternatives emerge through exploiting business opportunities [11]. The study conducted by Lahikainen et al. [60] confirms that establishing a flourishing entrepreneurial university ecosystem requires collaboration and contribution from all stakeholders at both internal and external levels. Institutions such as universities have a particular responsibility to support entrepreneurship and develop regional entrepreneurial growth [3].

Beyond generating knowledge with commercial potential and qualified research scientists, universities produce other knowledge-transfer mechanisms, such as attracting talent to the local economy and collaborating with local industry by providing formal and informal technical support [61]. The capacity for firm-based learning in a region depends on their ability to exploit both external, codified, and reproducible knowledge, which is often university-generated, along with the ability to develop and assess person-embodied, tacit knowledge. From this viewpoint, universities are versatile actors capable of producing knowledge and human capital and are institutional drivers for active support, enduring networks, and knowledge flows [61].

The economic impact of universities is significant in the entrepreneurial ecosystem, as proved by Carayannis et al. [6]. However, the role of entrepreneurial universities in the entrepreneurial initiative is less well understood than is often presumed [61].

Donegan et al. [45] recognize that regions have different resources available and support entrepreneurs using distinctive strategies to enable business development. Creating a vibrant entrepreneurial environment can be endangered in an EU context by a hostile campus that undermines incentives to transfer knowledge or commercial opportunities. As mentioned by the author, although academic entrepreneurs frequently produce products and processes that can be recognized as commercial opportunities, they face restrictions when starting their entrepreneurial journey, related to knowledge transfer mechanisms.

To summarize, an entrepreneurial initiative requires multidimensional analysis, where individual and contextual factors compete to define what ignites the new business creation process [62]. Therefore, as demonstrated, entrepreneurial ecosystems, the entrepreneurial university, and entrepreneurial initiative share a close relationship and mutually contribute to reinforcing entrepreneurship. From this viewpoint, the proposed conceptual framework (Figure 1) entails the link between the entrepreneurial university and entrepreneurial initiative, considering entrepreneurial ecosystem quality and controlling individual characteristics. 


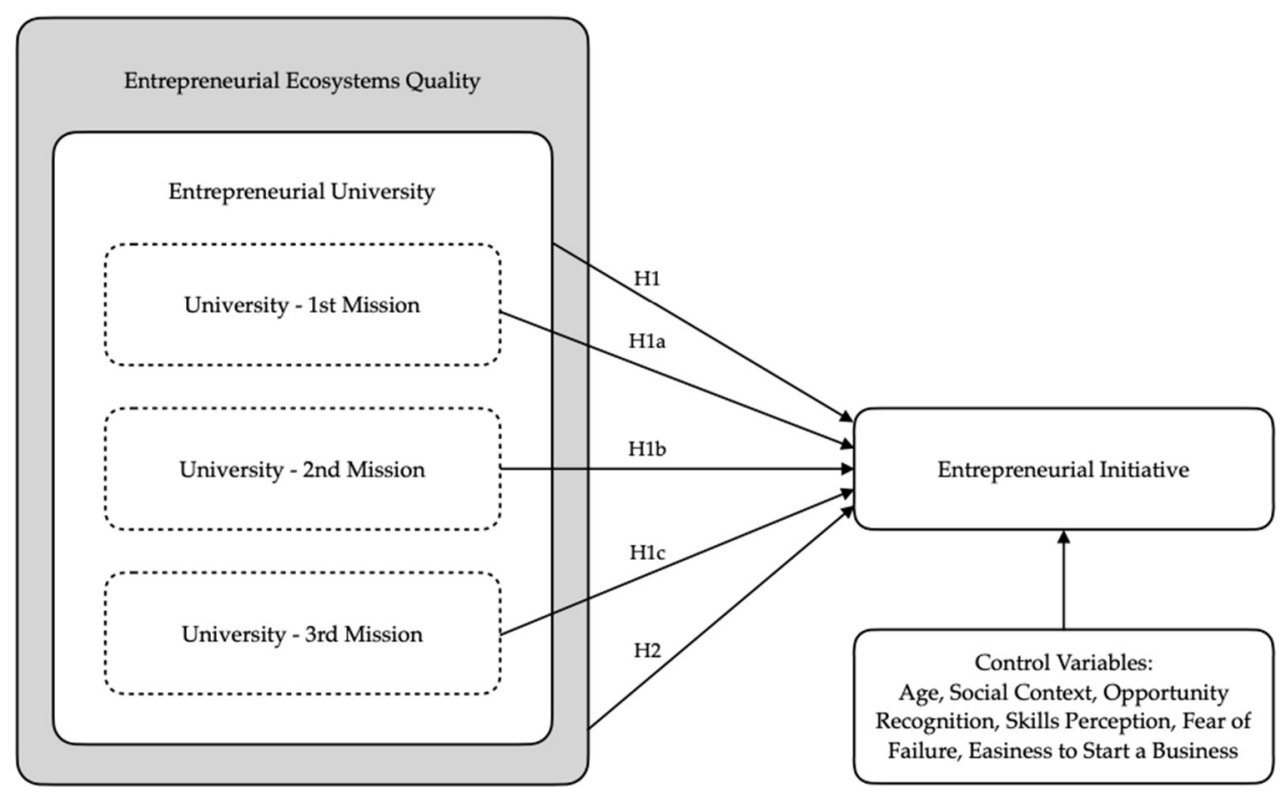

Figure 1. Conceptual framework.

\section{Methodology}

\subsection{Research Design and Sample}

As the literature suggests [24], entrepreneurship can be measured by multiple perspectives, such as considering nascent entrepreneurs or owner-managers of firms. Therefore, the dependent variable - entrepreneurial initiative-aims to capture the initial efforts of entrepreneurs in setting up a business.

The data comes from two large archival datasets: a Global Entrepreneurship Monitor (GEM) survey from 2017 and the European Innovation Scoreboard (EIS) 2017, since it is the latest dataset from GEM that is publicly available. Both databases are reliable and well-respected resources related to entrepreneurship and innovation. A total of 76,030 individuals represents the sample of the study, characterizing 18 European countries.

\subsection{Variables and Measures}

\subsubsection{Dependent Variable}

All the variables are presented in Table 3. The entrepreneurial initiative appraises how many individuals attempted to create new firms [24] at an early stage. Therefore, total earlystage entrepreneurial activity (TEA), commonly used as a proxy to assess entrepreneurship [58], was not considered within the study, as it comprises the complete venture life cycle phases (nascent, new venture, established venture, and discontinuation) [63]. Thus, the independent variable is that of entrepreneurial initiative and corresponds to the GEM measure of individuals trying to start a business (BSTART), extracted from the GEM-Adult Population Survey (APS). The variable reflects the active engagement of individuals in developing new businesses, as is consistent with the study by Bosma [23], using a binary code where " 0 " corresponds to those who are not involved in entrepreneurial efforts and "1" for everyone else. EE arises from the Global Entrepreneurship Monitor-Expert Survey (GEM NES) 2017 and is operated following the entrepreneurial ecosystem quality control proposed by Pita et al. [55]. This measure brings to light the differences between entrepreneurial ecosystems and their positioning according to their quality. GEM NES offers valuable data for understanding the dissimilarities between EE across countries [64]. 
Table 3. Variables.

\begin{tabular}{|c|c|c|c|}
\hline Dependent variable & Description & Source & Type \\
\hline $\begin{array}{l}\text { Entrepreneurial } \\
\text { Initiative }\end{array}$ & $\begin{array}{l}\text { Individual's initiative to start a } \\
\text { business }\end{array}$ & $\begin{array}{l}\text { Global Entrepreneurship } \\
\text { Monitor } 2017\end{array}$ & Binary \\
\hline Independent variables & Description & Source & Type \\
\hline $\begin{array}{c}\text { Universities 1st Mission-Teaching } \\
\text { Activities }\end{array}$ & Individual's educational level & $\begin{array}{l}\text { Global Entrepreneurship } \\
\text { Monitor } 2017\end{array}$ & Binary \\
\hline $\begin{array}{c}\text { Universities } 2 \text { 2nd Mission-Research } \\
\text { Activities }\end{array}$ & $\begin{array}{c}\text { The attractiveness of the research } \\
\text { system }\end{array}$ & $\begin{array}{l}\text { European Innovation } \\
\text { Scoreboard } 2017\end{array}$ & Binary \\
\hline $\begin{array}{l}\text { Universities 3rd } \\
\text { Mission-Entrepreneurial Activities }\end{array}$ & $\begin{array}{l}\text { The flow of knowledge between public } \\
\text { and private sectors to serve innovation } \\
\text { and entrepreneurship. }\end{array}$ & $\begin{array}{l}\text { European Innovation } \\
\text { Scoreboard } 2017\end{array}$ & Binary \\
\hline Control variables & Description & Source & Type \\
\hline $\begin{array}{l}\text { Gender } \\
\text { (GEN) }\end{array}$ & Individual's gender & $\begin{array}{l}\text { Global Entrepreneurship } \\
\text { Monitor } 2017\end{array}$ & Binary \\
\hline $\begin{array}{l}\text { Age } \\
\text { (AGE) }\end{array}$ & Individual's age & $\begin{array}{l}\text { Global Entrepreneurship } \\
\text { Monitor } 2017\end{array}$ & Multinomial \\
\hline $\begin{array}{l}\text { Social Context } \\
\quad(\text { SOC })\end{array}$ & $\begin{array}{l}\text { Entrepreneurial activity in the } \\
\text { individual's close environment }\end{array}$ & $\begin{array}{l}\text { Global Entrepreneurship } \\
\text { Monitor } 2017\end{array}$ & Binary \\
\hline $\begin{array}{c}\text { Opportunity Recognition } \\
\text { (OPR) }\end{array}$ & $\begin{array}{l}\text { Individual's business opportunity } \\
\text { recognition }\end{array}$ & $\begin{array}{l}\text { Global Entrepreneurship } \\
\text { Monitor } 2017\end{array}$ & Binary \\
\hline $\begin{array}{l}\text { Skills Perception } \\
\text { (SKP) }\end{array}$ & $\begin{array}{l}\text { Individual's knowledge, skills, and } \\
\text { experience }\end{array}$ & $\begin{array}{l}\text { Global Entrepreneurship } \\
\text { Monitor } 2017\end{array}$ & Binary \\
\hline $\begin{array}{l}\text { Fear of Failure } \\
\quad(F O F)\end{array}$ & Individual's fear of failure & $\begin{array}{l}\text { Global Entrepreneurship } \\
\text { Monitor } 2017\end{array}$ & Binary \\
\hline $\begin{array}{l}\text { Easiness to Start } \\
\text { (ESS) }\end{array}$ & $\begin{array}{c}\text { Individual's perception of ease of } \\
\text { starting a business }\end{array}$ & $\begin{array}{l}\text { Global Entrepreneurship } \\
\text { Monitor } 2017\end{array}$ & Binary \\
\hline
\end{tabular}

\subsubsection{Independent Variables}

The independent variable is the entrepreneurial university. The entrepreneurial university is measured by three proxies corresponding to the different missions: education (first mission), research (second mission) and entrepreneurial orientation (third mission). The variables are proxied by GEM 2017 and the European Innovation Scoreboard (EIS) 2017 databases and specific indicators [65]. The first mission is grounded in human capital expertise, obtained using the "Education" variable. For the purposes of this study, the variable was transformed from ordinal to binary, with " 0 " corresponding to individuals with no tertiary education and " 1 " for tertiary education, presenting higher human capital. The second mission-research-is measured using the proxy for "Attractive research systems" from EIS2017, obtained from a combination of international scientific co-publications, mostcited publications, and foreign doctorates. Following a similar procedure, this variable was turned from continuous to binary, with " 0 " corresponding to inferior performance and " 1 " showing superior performance relative to the average. The third mission is measured through "Linkages", which reflects the collaboration between innovative SMEs, publicprivate co-publications, and private co-funding of public R\&D expenditures. This variable represents the entrepreneurial orientation of universities as they are engaged in formal and informal activities to expand teaching and research pillars throughout entrepreneurship. Following a similar procedure, the variable was changed from continuous to binary, with a similar correspondence. The methodological options regarding the transformation of variables obtained three measures based on performance assessment (lower or higher).

\subsubsection{Control Variables}

According to the entrepreneurial ecosystem where entrepreneurs are embedded, entrepreneurial initiative may vary. The measures were all extracted from GEM APS. The 
control variables include "Gender", "Age", “Education", “Social Context", “Opportunity Recognition", "Skills Perception", "Fear of Failure" and "Easiness of Start".

\section{Research Methods}

The data were analyzed using linear logistic regression, following the example of prior studies [66] in the field. The empirical analysis was conducted in three steps, aiming to test the proposed hypotheses. First, considering the overall dataset from GEM 2017, the calculation of the entrepreneurial ecosystem quality (EEQ) of countries was performed, following the taxonomic approach proposed by Pita et al. [55]. As a result, 54 countries were distributed, according to four economic positions-Die Hard, Go-Getter, Sugar-Coated and Front Runners-revealing an unexpected prevalence of European countries with a lower entrepreneurial initiative. Second, the dataset was purified to include only European countries. The procedure allowed 18 countries to be included, distributed among the DieHard (Greece, Spain, Italy, United Kingdom, Poland, Cyprus, Bulgaria, Croatia, Slovenia, Slovakia) and Sugar-Coated (Netherlands, France, Sweden, Germany, Luxembourg, Ireland, Latvia, Estonia) positions. Therefore, EEQ was considered for the sectional cut of the sample. The last step was devoted to testing the hypotheses using four different models. Model 1 tested the effect of the entrepreneurial university on entrepreneurial initiative for the whole sample. Model 2 allowed testing of the role of the EU in EI within two groups-Die-Hard and Sugar-Coated.

\section{Results and Discussion}

\subsection{Findings}

Table 4 offers a descriptive overview of the sample, with details of the respondents. Considering the methodological procedures followed by GEM $[23,24]$, the sample is balanced according to the gender of respondents. Regarding entrepreneurial initiative, only $6.51 \%$ of respondents are attempting to start a business. Concerning the measures for entrepreneurial universities, the descriptive summary highlights two interesting facts. First, in all three missions, the performance of universities is consistently below the average. Second, the third mission exhibits better results when compared to the other two, highlighting its importance. This analysis presents an exciting finding: although teaching and research are traditional activities, universities are becoming more entrepreneurial. After decades of building new knowledge and contributing to shedding light on research, universities have seized on the importance of becoming more entrepreneurial. As for control variables, the sample also evidences another curious fact: only one-third of individuals would contact entrepreneurs in their social context. In the same line, an equal portion considers that starting a business is an easy challenge. This perspective is aligned with the fear of failure, since nearly half of the sample affirmed that fear of failure would prevent them from starting a business. Similarly, individuals tend to declare the lack of proper skills, knowledge, and competencies to engage in an entrepreneurial journey. Lastly, the majority do not recognize future business opportunities.

Table 4. Characterization of variables.

\begin{tabular}{|c|c|c|c|c|c|c|c|}
\hline Variable & & $\mathbf{N}$ & $\%$ & Variable & & $\mathbf{N}$ & $\%$ \\
\hline \multirow{3}{*}{$\begin{array}{l}\text { Ent. Initiative } \\
\text { (EI) }\end{array}$} & $\mathrm{No}$ & 71081 & 93.49 & \multirow{3}{*}{$\begin{array}{l}\text { Gender } \\
(\mathrm{GEN})\end{array}$} & Male & 27028 & 49.65 \\
\hline & Yes & 4949 & 6.51 & & Female & 27414 & 50.35 \\
\hline & Total & 76030 & 100 & & Total & 54442 & 100 \\
\hline \multirow{3}{*}{$\begin{array}{l}\text { First mission } \\
\quad(\mathrm{U} 1 \mathrm{M})\end{array}$} & Lower & 53225 & 72.17 & \multirow{3}{*}{$\begin{array}{l}\text { Social Context } \\
\text { (SOC) }\end{array}$} & No & 50224 & 66.79 \\
\hline & Higher & 20521 & 27.83 & & Yes & 24977 & 33.21 \\
\hline & Total & 73746 & 100 & & Total & 75201 & 100 \\
\hline \multirow{3}{*}{$\begin{array}{l}\text { Second mission } \\
\text { (U 2M) }\end{array}$} & Lower & 52203 & 68.23 & \multirow{3}{*}{$\begin{array}{l}\text { Skills Perception } \\
\text { (SKP) }\end{array}$} & No & 40743 & 56.09 \\
\hline & Higher & 24310 & 31.77 & & Yes & 31895 & 43.91 \\
\hline & Total & 76513 & 100 & & Total & 72638 & 100 \\
\hline
\end{tabular}


Table 4. Cont.

\begin{tabular}{|c|c|c|c|c|c|c|c|}
\hline Variable & & $\mathbf{N}$ & $\%$ & Variable & & $\mathbf{N}$ & $\%$ \\
\hline \multirow{3}{*}{$\begin{array}{l}\text { Third Mission } \\
\text { (U 3M) }\end{array}$} & Lower & 47780 & 62.45 & \multirow{3}{*}{$\begin{array}{c}\text { Fear of Failure } \\
(\text { FOF })\end{array}$} & No & 39293 & 54.84 \\
\hline & Higher & 28733 & 37.55 & & Yes & 32354 & 45.16 \\
\hline & Total & 76513 & 100 & & Total & 71647 & 100 \\
\hline \multirow{7}{*}{$\begin{array}{l}\text { Age } \\
(\mathrm{AGE})\end{array}$} & L1 & 5883 & 11.15 & \multirow{3}{*}{$\begin{array}{c}\text { Easiness to Start } \\
\text { (ESS) }\end{array}$} & No & 33802 & 64.48 \\
\hline & L2 & 10077 & 19.09 & & Yes & 18623 & 35.52 \\
\hline & L3 & 11925 & 22.59 & & Total & 52425 & 100 \\
\hline & $\mathrm{L} 4$ & 11918 & 22.58 & \multirow{4}{*}{$\begin{array}{l}\text { Op. Recognition } \\
\text { (OPR) }\end{array}$} & No & 34867 & 59.74 \\
\hline & L5 & 10892 & 20.64 & & Yes & 23493 & 40.26 \\
\hline & L6 & 2088 & 3.96 & & Total & 58360 & 100 \\
\hline & Total & 52783 & 100 & & & & \\
\hline
\end{tabular}

The correlations between variables are displayed in Table 5. Although there is a correlation between variables for the second and third missions, the values are moderate, and do not represent a multicollinearity problem for regression.

Table 5. Summary statistics and correlations matrix.

\begin{tabular}{|c|c|c|c|c|c|c|c|c|c|c|c|c|c|c|}
\hline & $\mathbf{N}$ & Mean & SD & EI & $\mathbf{U} \mathbf{1} \mathbf{M}$ & $\mathrm{U} 2 \mathrm{M}$ & $\mathrm{U} 3 \mathbf{M}$ & GEN & AGE & SOC & OPR & SKP & FOF & ESS \\
\hline EI & 76030 & 0.07 & 0.247 & 1 & & & & & & & & & & \\
\hline $\mathbf{U} \mathbf{1 M}$ & 73746 & 0.28 & 0.448 & $\begin{array}{c}0.065 \\
* * *\end{array}$ & 1 & & & & & & & & & \\
\hline $\mathrm{U} 2 \mathrm{M}$ & 76513 & 0.32 & 0.466 & $\underset{* * *}{0.012}$ & $\begin{array}{c}0.169 \\
* * *\end{array}$ & 1 & & & & & & & & \\
\hline $\mathrm{U} 3 \mathbf{M}$ & 76513 & 0.38 & 0.484 & 0.001 & $\begin{array}{c}0.102 \\
* * *\end{array}$ & $\underset{* * *}{0.646}$ & 1 & & & & & & & \\
\hline GEN & 76513 & 0.50 & 0.500 & $\underset{* * *}{-0.062}$ & $\begin{array}{c}0.017 \\
* * *\end{array}$ & $\underset{* * *}{0.011}$ & -0.001 & 1 & & & & & & \\
\hline AGE & 67531 & 4.38 & 1.412 & $\underset{* * *}{-0.064}$ & $\underset{* * *}{-0.048}$ & $\underset{* * *}{0.115}$ & $\underset{* * *}{0.102}$ & $\underset{* * *}{0.028}$ & 1 & & & & & \\
\hline SOC & 75201 & 0.33 & 0.471 & $\underset{* * *}{0.154}$ & $\underset{* * *}{0.082}$ & $\underset{* * *}{-0.025}$ & $\underset{* * *}{-0.056}$ & $\underset{* * *}{-0.056}$ & $\underset{* * *}{-0.098}$ & 1 & & & & \\
\hline OPR & 75201 & 0.33 & 0.471 & $\underset{* * *}{0.111}$ & $\underset{* * *}{0.128}$ & $\underset{* * *}{0.106}$ & $\begin{array}{c}0.045 \\
* * *\end{array}$ & $\underset{* * *}{-0.060}$ & $\underset{* * *}{-0.051}$ & $\underset{* * *}{0.211}$ & 1 & & & \\
\hline SKP & 72638 & 0.44 & 0.496 & $\begin{array}{c}0.175 \\
* * *\end{array}$ & $\begin{array}{c}0.094 \\
* * *\end{array}$ & $\underset{* * *}{-0.041}$ & $\underset{* * *}{-0.033}$ & $\underset{* * *}{-0.115}$ & 0.002 & $\underset{* * *}{0.238}$ & $\begin{array}{c}0.142 \\
* * *\end{array}$ & 1 & & \\
\hline FOF & 71647 & 0.45 & 0.498 & $\underset{* * *}{-0.062}$ & $\underset{* * *}{-0.019}$ & $\underset{* * *}{-0.062}$ & $\underset{* * *}{-0.066}$ & $\underset{* * *}{0.065}$ & $\underset{* * *}{-0.071}$ & $\underset{* * *}{-0.046}$ & $\underset{* * *}{-0.092}$ & $\underset{* * *}{-0.156}$ & 1 & \\
\hline ESS & 71647 & 0.45 & 0.498 & $\begin{array}{c}0.030 \\
* * *\end{array}$ & $\begin{array}{c}0.058 \\
* * *\end{array}$ & $\begin{array}{c}0.226 \\
* * *\end{array}$ & $\begin{array}{c}0.140 \\
* * *\end{array}$ & $\underset{* * *}{-0.035}$ & $\underset{* * *}{0.018}$ & $\underset{* * *}{0.086}$ & $\underset{* * *}{0.252}$ & $\underset{* * *}{0.097}$ & $\underset{* * *}{-0.092}$ & 1 \\
\hline
\end{tabular}

*** Correlation is significant at the 0.01 level (2-tailed).

\subsection{Empirical Findings}

Table 6 reports the results of the regression analyses for Model 1 and Model 2. Considering the results, it can be understood that the entrepreneurial university does not have a linear effect in all models, and its missions affect entrepreneurial initiative differently. For Model 1, the regression does not take into account entrepreneurial ecosystem quality. Therefore, the effect of the EU is analyzed, neglecting the context. The results obtained evidence of the relevance of teaching and research activities for starting a business, while entrepreneurial activities are not significant. This finding can be intertwined with the importance of producing skilled human capital as a necessary condition to thrive in an uncertain environment, in both employment and self-employment scenarios. As for the importance of research, its significance can be interpreted as the university's ability to generate valuable research that is capable of transformation and being absorbed by industry and business agents. 
Table 6. Regressions.

\begin{tabular}{cccc}
\hline & Model 1 & \multicolumn{2}{c}{ Model 2 } \\
& All Sample & Die-Hard & Sugar-Coated \\
\hline U 1 Mission & $0.359^{* * * *}$ & $0.375^{* * * *}$ & 0.064 \\
& $(0.048)$ & $(0.058)$ & $(0.086)$ \\
U 2 Mission & $0.409^{* * *}$ & $1.123^{* * * *}$ & -0.169 \\
& $(0.074)$ & $(0.176)$ & $(0.139)$ \\
U 3 Mission & -0.065 & $0.330^{* * *}$ & $-0.603^{* * *}$ \\
& $(0.069)$ & $(0.079)$ & $(0.123)$ \\
Gender & $-0.300^{* * *}$ & $-0.256^{* * *}$ & $-0.402^{* * *}$ \\
Age & $(0.045)$ & $(0.053)$ & $(0.088)$ \\
& $-0.154^{* * *}$ & $-0.106^{* * *}$ & $-0.263^{* * *}$ \\
Social Context & $(0.017)$ & $(0.021)$ & $(0.030)$ \\
& $0.791^{* * *}$ & $0.777^{* * * *}$ & $0.878^{* * *}$ \\
Opportunity Recognition & $(0.047)$ & $(0.055)$ & $(0.090)$ \\
& $0.468^{* * *}$ & $0.557^{* * *}$ & $0.283^{* * *}$ \\
Skills Perception & $(0.047)$ & $(0.055)$ & $(0.091)$ \\
& $1.260^{* * *}$ & $1.229^{* * *}$ & $1.320^{* * *}$ \\
Fear of Failure & $(0.055)$ & $(0.066)$ & $(0.101)$ \\
& $-0.254^{* * *}$ & $-0.370^{* * *}$ & -0.075 \\
Easiness to Start & $(0.047)$ & $(0.057)$ & $(0.089)$ \\
& $-0.187^{* * *}$ & $-0.262^{* * *}$ & -0.014 \\
Constant & $(0.049)$ & $(0.060)$ & $(0.089)$ \\
& $-3.200^{* * *}$ & $-3.493^{* * *}$ & $-1.735^{* * *}$ \\
& $(0.096)$ & $(0.115)$ & $(0.187)$ \\
\hline
\end{tabular}

Note: $p<0.01^{* * *} ;$ SE (Standard Error) in parenthesis.

Concerning the third mission, although entrepreneurial activities aim to develop an entrepreneurial culture and mindset to foster new businesses and economic outputs, its statistical insignificance reveals that individuals are not affected by the environment. It can be concluded that universities are sources of knowledge where individuals can develop their skills and competencies and benefit from scientific research to raise expertise. Apart from the university environment, the characteristics of individuals also influence the desire to pursue an entrepreneurial career. The results confirm that gender negatively affects entrepreneurial initiative, showing women as less entrepreneurial when compared to men. The same occurs with age and fear of failure, both acting as discouraging factors. Negative perceptions about the environment and the strain on enterprise also discourage entrepreneurial initiative. All three factors contribute to pushing individuals to pursue alternative careers. In contrast, social context, opportunity recognition and skills perception contribute positively to fostering entrepreneurship.

The second model compares the effect of entrepreneurial universities on entrepreneurial initiative in two different entrepreneurial ecosystems. The Die-Hard group represents an EE with low quality. Therefore, the support conditions for enterprise are fragile. In this group, all three missions gain significance and are positive enhancers of EI. In a more positive environment, like the Sugar-Coated scenario, only the third mission is predominant, but with a negative effect. Teaching and research are not determinants to pursue entrepreneurship within this specific context. Similarly, for the Die-Hard group, gender and age are inhibitors of entrepreneurial initiative, while opportunity recognition and skills perception stimulate entrepreneurial endeavors. Surprisingly, fear of failure and easiness to start a business do not appear as significant for this type of EE.

To summarize, the entrepreneurial university plays a significant role in entrepreneurial initiative, but it is conditioned to the local environment in entrepreneurial ecosystems. Thus, while the first, second and third missions gain more relevance in less favorable contexts, entrepreneurial activities do not enhance the initiative of individuals to undertake an enterprise. 
The findings allow the extension of the EE literature through the lens of the EU and its effect on EI. Although entrepreneurial orientation is undoubtedly relevant as a way to broaden the scope of universities, the findings reveal a non-linearity effect concerning entrepreneurial initiative.

\subsection{Discussion}

Entrepreneurial ecosystems and entrepreneurial universities are in the forefront of entrepreneurship research, with academics and policymakers grasping for "winning" entrepreneurship strategies. While Europe defends a singular approach to entrepreneurship, countries struggle to overcome idiosyncrasies, evidencing the need to adjust policies at the local level. Several studies focus on vibrant EEs, such as Silicon Valley [67] or Stockholm [68] as an attempt to theorize about EEs diversity and resilience [69] to explain why some EEs persist while others do not thrive.

Stam and van de Ven [14] state that the essence of an ecosystem is the sum of its multiple elements, its diversity being broadened by the knowledge base [70]. Universities are, therefore, pillars of the creation, development, and exploitation of knowledge through their three missions. Despite interest in entrepreneurial universities and their contribution to the entrepreneurial initiative, universities have been rarely examined through the lens of their three missions, using an entrepreneurial ecosystem approach [71]. Moreover, the study examines if determinants of the entrepreneurial initiative are similar among different entrepreneurial ecosystems.

The empirical approach evidences some curious findings on theoretical, practical and policy levels. First, the results show that, in general, universities have a significant and positive impact on the entrepreneurial initiative through their first and second missions, while the third mission is irrelevant. This finding is surprising, since previous studies acknowledge the relevance of entrepreneurial activities within universities as a stimulus to entrepreneurial action [30,41]. This fact could be explained by the relevance of education, skills, and competencies for individuals to engage in an entrepreneurial journey. Individuals need to perceive they have the proper competencies for enterprise; otherwise, they will feel less confident.

Other variables deter individuals from pursuing entrepreneurial careers, such as gender, age, or fear of failure [72-74]. Although European countries attempt to even out age and gender differences, they still narrow the entrepreneurial initiative. One possible justification could rely on cultural aspects, such as the role of women at professional and family levels and the belief that older individuals tend to pursue stable occupations. In terms of fear of failure, European culture still neglects the importance of failing as part of growth, considering that it is connected to a lack of competencies or ability to overcome business challenges. In the United States, "the social norms" support the persistence of entrepreneurs, regarding failure as an opportunity to become more knowledgeable and experienced within the market. In Europe, successful entrepreneurs are considered to be role models, assuming a leading function to inspire, while those who fail tend to be overlooked. The results corroborate the importance of social context in influencing individuals to pursue entrepreneurship; it is surprising to find that contact with other entrepreneurs is more relevant than any university mission. Surprisingly, entrepreneurs are not affected by the ease of starting a business, which raises an important reminder at the policy level: the motivation to become entrepreneurial does not rely on physical infrastructures, financial sources, or easy procedures. Individuals become entrepreneurial because they choose to exploit an opportunity, believing that the value obtained will exceed the costs [46], looking to the EEs as a pool of resources that is capable of catalyzing the business [3].

The role of universities in entrepreneurial initiative is not linear when comparing two different entrepreneurial ecosystems. As proved by Model 2, universities are relevant in all three missions in more fragile environments. In a prosperous EEs, only the third mission is significant, but with an adverse result. These unexpected findings push academics and 
policymakers to a deeper reflection about the role of universities and the strategies to foster entrepreneurship, adapted to the conditions of the context: should universities strengthen their entrepreneurial orientation and make the third mission prevalent? The answer to the question, considering our results, indicates otherwise.

A Die-Hard ecosystem is characterized by minor levels of entrepreneurial initiative and conditions. In this setting, the institutional role of universities emerges as being central, providing multiple support for educational, research and entrepreneurial endeavors. Yet again, the first and second missions take on more importance as they reinforce recognition of individuals' opportunities for capital and leverage through research.

In a Sugar-Coated ecosystem, the quality of support conditions is higher and provides the needed backing for entrepreneurs concerning infrastructures, institutions, programs, or funding. However, despite the favorable circumstances, individuals tend to engage less in entrepreneurial efforts. Moreover, universities do not fulfill their multiple missions in this specific context, highlighting the need to search for different models to stimulate entrepreneurship. For instance, education can support individuals' competencies and skills, leveraging their preparedness for enterprise following non-traditional models; the recognition of opportunity can be enlarged using research-based activities to spread potential business, and social context can be spurred through role-modeling using nearby entrepreneurial networks.

Finally, our empirical findings place entrepreneurs as a central component of entrepreneurial universities, showing that the local environment affects entrepreneurial initiative differently. However, the favorability of certain conditions may reduce individuals" desire to start a business since there is a gap between "supply and demand". The entrepreneurial journey requires resilience and tenacity to thrive [75]; therefore, ecosystems must help entrepreneurs to develop their total capacity, making use of entrepreneurial universities to empower the academic community [76]. Entrepreneurial ecosystems and their elements [77] can be configured in multiple ways [15], but their development depends on specific "recipes" and "local" ingredients. Therefore, following the entrepreneurial ecosystem taxonomy proposed by Pita et al. [55], this allowed validation of the role of EUs in different EEs according to their quality, as suggested by Stam and van de Ven [14].

\section{Conclusions}

The growing interest in the topic of entrepreneurial universities and entrepreneurial initiative has flourished over time. Entrepreneurial ecosystems have gained research space as their influence on entrepreneurship has been more widely recognized. However, information on the relationship between the impact of entrepreneurial universities on the entrepreneurial initiative, through the lens of entrepreneurial ecosystems, is still scarce. The present research aims to provide empirical evidence about the heterogeneity of effects that the EU has on EI, conditioned to the EE.

Following the conceptual model, the results do not generally support the importance of entrepreneurial universities to entrepreneurial initiative, revealing a dissimilar effect of EUs, opening the discussion around two main aspects.

First, the disparities of the impact of EUs in different EEs confirm the need to have place-based entrepreneurship policies to boost entrepreneurial initiative. The different missions of universities are not equally significant in both scenarios. While universities fulfill their purposes in all dimensions in terms of Die-Hard ecosystems, in a Sugar-Coated environment, universities' flaws in education and research and the third mission have a negative impact on entrepreneurship. The relevance of entrepreneurial universities stands out in more fragile entrepreneurial ecosystems, since individuals need support in multiple dimensions. The results clearly demonstrate the importance of the first and second missions of universities to reinforce entrepreneurial competencies and entrepreneurial opportunities in such environments. From this perspective, entrepreneurial universities become a crucial element as other elements of the ecosystem are less structured and developed. Differently, entrepreneurial universities embedded in stronger entrepreneurial 
ecosystems lose relevance and negatively affect the entrepreneurial initiative. Therefore, the value of EUs is reduced when individuals have greater support from other dimensions. The variation across both groups suggests that the $\mathrm{EU}$ is not a contemporaneous phenomenon, as its effect is progressively disclosed by the maturity of each mission. This perspective substantially changes the understanding of EUs as a thwartwise strategy, suggesting that the impact of universities increases when their missions gradually evolve. Therefore, EUs may have no effect on entrepreneurial initiative if education and research missions are not developed.

Second, despite the great promise that entrepreneurs take advantage of specific individual characteristics to start new businesses, the results demonstrate that individual determinants have a similar impact on entrepreneurial initiative, although comparing entrepreneurial ecosystems with very distinctive conditions. Only the fear of failure and the perception of easiness to start a business are not significant in high-quality entrepreneurial ecosystems. Such variation opens the debate around would-be entrepreneurs and how committed they are, while true entrepreneurs pledge themselves to an entrepreneurial career.

These findings validate previous studies that consider EEs a geographical phenomenon [3,77]. Furthermore, it recognizes that the EUs' impacts depend on individuals and context delimitations, which is in line with previous studies $[6,13]$. Universities may influence individuals to pursue entrepreneurship to some extent, as proved previously [78], but their effectiveness depends on the ability to design an EU that respects internal and external diversity to unlock the full potential of the overall community.

\subsection{Theoretical and Practical Implications}

Entrepreneurial ecosystems attract attention from academics, practitioners, and policymakers hoping to unlock "a winning recipe". Understanding the degree of influence of entrepreneurial universities and their missions on entrepreneurial initiative is helpful in framing better policies to unlock practical entrepreneurship. First, policymakers need to pay attention to the expected role of universities and their entrepreneurial orientation. Entrepreneurship can be overstated, as the separate purpose of each mission becomes indistinguishable, misaligning individuals' perceptions regarding the benefits of entrepreneurship. Second, the quality of education must improve the potential of human capital to leverage research exploitation. The entrepreneurial orientation of EUs must acknowledge individuals' diversity and what ignites entrepreneurship, to enable significant and impactful strategies. Otherwise, EUs will be detached from their communities, despite being a "land of entrepreneurship". Third, the irrelevance of the third mission in some cases opens a controversial debate, as entrepreneurship is seen as a "golden" formula.

The role of education and research must serve entrepreneurship, to ensure the encouragement of individuals to frame business development as an alternative. Therefore, the interconnection between both dimensions can have a complementary role in strengthening the effect of entrepreneurship measures. Hence, the convergence of interests around educational, industrial, and societal systems improves the potential motivation to pursue entrepreneurship.

Our study has several implications for entrepreneurship theory and practice, as well as public policy. First, the literature is highlighted through the empirical testing of EI determinants underlying the relationship between entrepreneurial universities and entrepreneurial ecosystems. As this discussion illustrates, most studies refer to entrepreneurship as being geographically bounded but lacking empirical support. Studies commonly discuss the EU effect without examining its multiple missions in depth. Thus, this study represents advancements in the fields of EUs and EEs, as it observes the phenomenon empirically and grasps for granular findings. Second, the analysis between EU and EI through a comparative study of different EEs suggests specific insights for policymakers and practitioners. As posited earlier, general strategies do not fit local purposes, with the disadvantage of wasting time and resources. The development of an EU embedded in specific EEs requires a significant investment in knowing what factors hamper entrepreneurship. Although 
European countries follow a common strategy, understanding the differences can be helpful in making economies more mature rather than engaging in flawed, generalized public policies to foster EI.

\subsection{Limitations and Future Research Directions}

This study focuses on the impact of entrepreneurial universities on entrepreneurial initiative in European countries. Although the data collection is limited to 18 countries, the examination of the EU in two different ecosystems allows advancements from the perspective of Spigel and Harrison [3]. First, to attain factual findings, this analysis should be recapped using a larger sample, including all European countries. An extension of this work is crucial to grasp why European countries are lagging behind in entrepreneurship, despite the global effort to build a common entrepreneurship strategy. Second, a new analysis could identify more context-specific entrepreneurship determinants. For that purpose, better measures could be included to assess entrepreneurial university missions. Third, future research should look to EUs and EEs as evolving, which calls for longitudinal analysis over at least four years. With this perspective, it is expected that the dynamic changes in systems can be identified.

Author Contributions: Conceptualization, M.P., J.C. and A.C.M.; methodology, M.P., J.C. and A.C.M.; validation, M.P., J.C. and A.C.M.; formal analysis, M.P., J.C., A.C.M.; investigation, M.P., J.C. and A.C.M.; resources, M.P., J.C. and A.C.M.; data curation, M.P., J.C. and A.C.M.; writing—original draft preparation, M.P.; writing-review and editing, M.P., J.C. and A.C.M.; visualization, M.P.; supervision, J.C. and A.C.M.; project administration, M.P., J.C. and A.C.M. All authors have read and agreed to the published version of the manuscript.

Funding: This research received no external funding.

Institutional Review Board Statement: Not applicable.

Informed Consent Statement: Not applicable.

Data Availability Statement: Not applicable.

Conflicts of Interest: The authors declare no conflict of interest.

\section{References}

1. Malecki, E.J. Entrepreneurship and entrepreneurial ecosystems. Geogr. Compass 2018, 12, e12359. [CrossRef]

2. Roundy, P.T.; Bradshaw, M.; Brockman, B.K. The emergence of entrepreneurial ecosystems: A complex adaptive systems approach. J. Bus. Res. 2018, 86, 1-10. [CrossRef]

3. Spigel, B.; Harrison, R. Toward a process theory of entrepreneurial ecosystems. Strat. Entrep. J. 2017, 12, 151-168. [CrossRef]

4. WEF. Leveraging Entrepreneurial Ambition and Innovation: A Global Perspective on Entrepreneurship, Competitiveness and Development; WEF: Cologny, Switzerland; Geneva, Switzerland, 2015; Available online: http://www3.weforum.org/docs/WEFUSA_ EntrepreneurialInnovation_Report.pdf\%5Cncontact@weforum.org (accessed on 28 June 2021).

5. EC. Entrepreneurship 2020 Action Plan: Reigniting the Entrepreneurial Spirit in Europe; EC: Brussels, Belgium, 2013.

6. Carayannis, E.G.; Cherepovitsyn, A.Y.; Ilinova, A.A. Technology commercialization in entrepreneurial universities: The US and Russian experience. J. Technol. Transf. 2015, 41, 1135-1147. [CrossRef]

7. Audretsch, D.B.; Aldridge, T.T.; Sanders, M. Social capital building and new business formation: A case study in Silicon Valley. Int. Small Bus. J. Res. Entrep. 2011, 29, 152-169. [CrossRef]

8. Roberts, E.B. Entrepreneurial Impact: The Role of MIT. Found. Trends®Entrep. 2011, 7, 1-149. [CrossRef]

9. Shane, S.A. Academic Entrepreneurship: University Spinoffs and Wealth Creation; Edward Elgar Publishing: Northampton, MA, USA, 2004

10. Etzkowitz, H. Innovation in Innovation: The Triple Helix of University-Industry-Government Relations. Soc. Sci. Inf. 2003, 42, 293-337. [CrossRef]

11. Guerrero, M.; Urbano, D. The development of an entrepreneurial university. J. Technol. Transf. 2010, 37, 43-74. [CrossRef]

12. Davey, T.; Hannon, P.; Penaluna, A. Entrepreneurship education and the role of universities in entrepreneurship: Introduction to the special issue. Ind. High. Educ. 2016, 30, 171-182. [CrossRef]

13. Audretsch, D.B.; Keilbach, M. Entrepreneurship and regional growth: An evolutionary interpretation. J. Evol. Econ. 2004, 14, 605-616. [CrossRef]

14. Stam, E.; van de Ven, A. Entrepreneurial ecosystem elements. Small Bus. Econ. 2019, 56, 809-832. [CrossRef]

15. Spigel, B. The Relational Organization of Entrepreneurial Ecosystems. Entrep. Theory Pract. 2017, 41, 49-72. [CrossRef] 
16. Acs, Z.J.; Stam, E.; Audretsch, D.B.; O'Connor, A. The lineages of the entrepreneurial ecosystem approach. Small Bus. Econ. 2017, 49,1-10. [CrossRef]

17. Autio, E.; Levie, J. Management of Entrepreneurial Ecosystems. In The Wiley Handbook of Entrepreneurship; Wiley: Hoboken, NJ, USA, 2017; pp. 423-449. [CrossRef]

18. Roundy, P.; Bayer, M.A. To bridge or buffer? A resource dependence theory of nascent entrepreneurial ecosystems. J. Entrep. Emerg. Econ. 2019, 11, 550-575. [CrossRef]

19. Wurth, B.; Stam, E.; Spigel, B. Toward an Entrepreneurial Ecosystem Research Program. Entrep. Theory Pract. 2021, 43, 1-16. [CrossRef]

20. Stam, E. Entrepreneurial Ecosystems and Regional Policy: A Sympathetic Critique. Eur. Plan. Stud. 2015, 23, 1759-1769. [CrossRef]

21. Mack, E.; Mayer, H. The evolutionary dynamics of entrepreneurial ecosystems. Urban. Stud. 2015, 53, 2118-2133. [CrossRef]

22. Roundy, P.T.; Fayard, D. Dynamic Capabilities and Entrepreneurial Ecosystems: The Micro-Foundations of Regional Entrepreneurship. J. Entrep. 2018, 28, 94-120. [CrossRef]

23. Bosma, N. The Global Entrepreneurship Monitor (GEM) and Its Impact on Entrepreneurship Research. Found. Trends®Entrep. 2013, 9, 143-248. [CrossRef]

24. Reynolds, P.; Bosma, N.; Autio, E.; Hunt, S.; De Bono, N.; Servais, I.; Lopez-Garcia, P.; Chin, N. Global Entrepreneurship Monitor: Data Collection Design and Implementation 1998-2003. Small Bus. Econ. 2005, 24, 205-231. [CrossRef]

25. Levie, J.; Autio, E. Entrepreneurial Framework Conditions and National-Level Entrepreneurial Activity: Seven-Year Panel Study. Third Glob. Entrep. Res. Conf. 2007, 14,1-39. Available online: http:// citeseerx.ist.psu.edu/viewdoc/download?doi=10.1.1.462 $.6312 \&$ rep $=$ rep $1 \&$ type $=$ pdf\%0Ahttp: / / www.gemconsortium.org/assets / uploads /1326045129Entrepreneurial_Framework_ Conditions.pdf (accessed on 28 June 2021).

26. Hogendoorn, B.; Rud, I.; Groot, W.; Brink, H.M.V.D. The Effects of Human Capital Interventions on Entrepreneurial Performance in Industrialized Countries. J. Econ. Surv. 2019, 33, 798-826. [CrossRef]

27. Siegel, D.S.; Wright, M. Academic Entrepreneurship: Time for a Rethink? Br. J. Manag. 2015, 26, 582-595. [CrossRef]

28. Clark, B.R.; Pergamon, B.R.; Clarkin, B.C. Creating Entrepreneurial Universities: Organizational Pathways of Transformation; Emerald Publishing Limited: Bingley, UK, 1998; pp. 127-148.

29. Pinheiro, R.; Stensaker, B. Designing the Entrepreneurial University: The Interpretation of a Global Idea. Public Organ. Rev. 2013, 14, 497-516. [CrossRef]

30. Guerrero, M.; Cunningham, J.A.; Urbano, D. Economic impact of entrepreneurial universities' activities: An exploratory study of the United Kingdom. Res. Policy 2015, 44, 748-764. [CrossRef]

31. Urbano, D.; Guerrero, M. Entrepreneurial Universities: Socioeconomic Impacts of Academic Entrepreneurship in a European Region. Econ. Dev. Q. 2013, 27, 40-55. [CrossRef]

32. Hannon, P.D. Letter from Academia Why is the Entrepreneurial University Important? The Need for the Entrepreneurial University. J. Innov. Manag. 2013, 1, 10-17. [CrossRef]

33. Philpott, K.; Dooley, L.; O'Reilly, C.; Lupton, G. The entrepreneurial university: Examining the underlying academic tensions. Technovation 2011, 31, 161-170. [CrossRef]

34. D'Este, P.; Perkmann, M. Why do academics engage with industry? The entrepreneurial university and individual motivations. J. Technol. Transf. 2010, 36, 316-339. [CrossRef]

35. Guan, J.; Zhao, Q. The impact of university-industry collaboration networks on innovation in nanobiopharmaceuticals. Technol. Forecast. Soc. Chang. 2013, 80, 1271-1286. [CrossRef]

36. Jarohnovich, N.; Avotinš, C.V. The Changing Role of the Entrepreneurial University in Developing Countries: The Case of Latvia. J. High. Educ. Theory Pract. 2013, 13, 121-149.

37. Guerrero, M.; Urbano, D.; Cunningham, J.; Organ, D. Entrepreneurial universities in two European regions: A case study comparison. J. Technol. Transf. 2012, 39, 415-434. [CrossRef]

38. Etzkowitz, H. The Entrepreneurial University Wave. Ind. High. Educ. 2014, 28, 223-232. [CrossRef]

39. Frondizi, R.; Fantauzzi, C.; Colasanti, N.; Fiorani, G. The Evaluation of Universities' Third Mission and Intellectual Capital: Theoretical Analysis and Application to Italy. Sustainability 2019, 11, 3455. [CrossRef]

40. Inzelt, A. The evolution of university-industry-government relationships during transition. Res. Policy 2004, 33, 975-995. [CrossRef]

41. Etzkowitz, H.; Webster, A.; Gebhardt, C.; Terra, B.R.C. The future of the university and the university of the future: Evolution of ivory tower to entrepreneurial paradigm. Res. Policy 2000, 29, 313-330. [CrossRef]

42. Sengupta, A.; Ray, A.S. University research and knowledge transfer: A dynamic view of ambidexterity in British universities. Res. Policy 2017, 46, 881-897. [CrossRef]

43. Isenberg, D. The Entrepreneurship Ecosystem Strategy as a New Paradigm for Economic Policy: Principles for Cultivating Entrepreneurships. Babson. 2011. Available online: http://www.innovationamerica.us/images/stories/2011/Theentrepreneurship-ecosystem-strategy-for-economic-growth-policy-20110620183915.pdf (accessed on 28 June 2021).

44. Pittz, T.G.; Hertz, G. A relational perspective on entrepreneurial ecosystems: The role and sustenance of the entrepreneurship center. J. Enterprising Communities People Places Glob. Econ. 2018, 12, 220-231. [CrossRef] 
45. Donegan, M.; Forbes, A.; Clayton, P.; Polly, A.; Feldman, M.; Lowe, N. The tortoise, the hare, and the hybrid: Effects of prior employment on the development of an entrepreneurial ecosystem. Ind. Corp. Chang. 2019, 28, 899-920. [CrossRef]

46. Cantner, U.; Cunningham, J.A.; Lehmann, E.E.; Menter, M. Entrepreneurial ecosystems: A dynamic lifecycle model. Small Bus. Econ. 2021, 57, 407-423. [CrossRef]

47. Dubina, I.; Campbell, D.F.J; Carayannis, E.; Chub, A.; Grigoroudis, E.; Kozhevina, O. The Balanced Development of the Spatial Innovation and Entrepreneurial Ecosystem Based on Principles of the Systems Compromise: A Conceptual Framework. J. Knowl. Econ. 2016, 8, 438-455. [CrossRef]

48. Roundy, P.T.; Fayard, D. Place-Based Advantages in Entrepreneurship: How Entrepreneurial Ecosystem Coordination Reduces Transaction Costs. JBAM 2020, 20, 115-136. [CrossRef]

49. Brown, R.C.; Mason, C. Looking inside the spiky bits: A critical review and conceptualization of entrepreneurial ecosystems. Small Bus. Econ. 2017, 49, 11-30. [CrossRef]

50. Isenberg, D. The big idea: How to start an entrepreneurial revolution. Harv. Bus. Rev. 2010, 88, 6.

51. Mason, C.; Brown, R. Entrepreneurial Ecosystems and Growth Oriented Entrepreneurship; The University of Glasgow: Glasgow, UK, 2014.

52. Feldman, M.; Siegel, D.S.; Wright, M. New developments in innovation and entrepreneurial ecosystems. Ind. Corp. Chang. 2019, 28, 817-826. [CrossRef]

53. Xu, Z.; Dobson, S. Challenges of building entrepreneurial ecosystems in peripheral places. J. Entrep. Public Policy 2019, 8, 408-430. [CrossRef]

54. Kuckertz, A. Let's take the entrepreneurial ecosystem metaphor seriously! J. Bus. Ventur. Insights 2019, 11, e00124. [CrossRef]

55. Pita, M.; Costa, J.; Moreira, A. Entrepreneurial Ecosystems and Entrepreneurial Initiative: Building a Multi-Country Taxonomy. Sustainability 2021, 13, 4065. [CrossRef]

56. Bercovitz, J.; Feldman, M.P. Entrepreneurial Universities and Technology Transfer: A Conceptual Framework for Understanding Knowledge-Based Economic Development. J. Technol. Transf. 2005, 31, 175-188. [CrossRef]

57. Venkataraman, S. Regional transformation through technological entrepreneurship. J. Bus. Ventur. 2004, 19, 153-167. [CrossRef]

58. Acs, Z.; Amorós, J.E.; Bosma, N.; Levie, J. From Entrepreneurship to Economic Development: Celebrating Ten Years of Global Entrepreneurship Monitor. Front. Entrep. Res. 2009, 29, 1-15. Available online: http://digitalknowledge.babson.edu/fer/vol29/ iss16/1/ (accessed on 28 June 2021).

59. Audretsch, D.B.; Peña-Legazkue, I. Entrepreneurial activity and regional competitiveness: An introduction to the special issue. Small Bus. Econ. 2011, 39, 531-537. [CrossRef]

60. Lahikainen, K.; Kolhinen, J.; Ruskovaara, E.; Pihkala, T. Challenges to the development of an entrepreneurial university ecosystem: The case of a Finnish university campus. Ind. High. Educ. 2018, 33, 96-107. [CrossRef]

61. Bramwell, A.; Wolfe, D.A. Universities and regional economic development: The entrepreneurial University of Waterloo. Res. Policy 2008, 37, 1175-1187. [CrossRef]

62. Sahasranamam, S.; Nandakumar, M. Individual capital and social entrepreneurship: Role of formal institutions. J. Bus. Res. 2018, 107, 104-117. [CrossRef]

63. GEM. GEM Methodology: Definitions. Global Entrepreneurship Monitor. 2021. Available online: https://www.gemconsortium. org/wiki/1154 (accessed on 27 January 2021).

64. Hechavarría, D.M.; Ingram, A.E. Entrepreneurial ecosystem conditions and gendered national-level entrepreneurial activity: A 14-year panel study of GEM. Small Bus. Econ. 2018, 53, 431-458. [CrossRef]

65. Hollanders, H.; Es-Sadki, N.; Vértesy, D.; Damioli, G. European Innovation Scoreboard 2017-Methodology Report. 2017. Available online: https: / / ec.europa.eu (accessed on 28 June 2021).

66. Van Trang, T.; Do, Q.H.; Luong, M.H. Entrepreneurial human capital, role models, and fear of failure and start-up perception of feasibility among adults in Vietnam. Int. J. Eng. Bus. Manag. 2019, 11. [CrossRef]

67. Kantis, H.; Federico, J. A dynamic model of entrepreneurial ecosystems evolution. J. Evol. Stud. Bus. JESB 2020, 5, 182-220. [CrossRef]

68. Roundy, P.T. The wisdom of ecosystems: A transactive memory theory of knowledge management in entrepreneurial ecosystems. Knowl. Process. Manag. 2020, 27, 234-247. [CrossRef]

69. Roundy, P.T.; Brockman, B.K.; Bradshaw, M. The resilience of entrepreneurial ecosystems. J. Bus. Ventur. Insights 2017, 8, 99-104. [CrossRef]

70. Roundy, P. “Small town” entrepreneurial ecosystems. J. Entrep. Emerg. Econ. 2017, 9, 238-262. [CrossRef]

71. Riviezzo, A.; Santos, S.C.; Liñán, F.; Napolitano, M.R.; Fusco, F. European universities seeking entrepreneurial paths: The moderating effect of contextual variables on the entrepreneurial orientation-performance relationship. Technol. Forecast. Soc. Chang. 2018, 141, 232-248. [CrossRef]

72. Heilman, M.E. Description and Prescription: How Gender Stereotypes Prevent Women's Ascent Up the Organizational Ladder. J. Soc. Issues 2001, 57, 657-674. [CrossRef]

73. Wang, J.; Li, Y.; Long, D. Gender gap in entrepreneurial growth ambition: The role of culturally contingent perceptions of the institutional environment in China. Int. J. Entrep. Behav. Res. 2019, 25, 1283-1307. [CrossRef]

74. Minniti, M.; Nardone, C. Being in Someone Else's Shoes: The Role of Gender in Nascent Entrepreneurship. Small Bus. Econ. 2007, 28, 223-238. [CrossRef] 
75. Lux, A.; Macau, F.R.; Brown, K.A. Putting the entrepreneur back into entrepreneurial ecosystems. Int. J. Entrep. Behav. Res. 2020, 26, 1011-1041. [CrossRef]

76. Gibb, A.; Hofer, A.-R.; Klofsten, M. The Entrepreneurial and Innovative Higher Education Institution: A Review of the Concept and its Relevance Today. Brussels. 2018. Available online: https:/ / heinnovate.eu/en/ (accessed on 28 June 2021).

77. Stam, P. Entrepreneurial Ecosystems. 2014. Available online: https://ideas.repec.org/p/use/tkiwps/1613.html (accessed on 28 June 2021).

78. Fayolle, A.; Gailly, B. The Impact of Entrepreneurship Education on Entrepreneurial Attitudes and Intention: Hysteresis and Persistence. J. Small Bus. Manag. 2015, 53, 75-93. [CrossRef] 